\title{
Rearing larvae of dusky grouper, Epinephelus marginatus (Lowe, 1834), (Pisces: Serranidae) in a semi-extensive mesocosm
}

\author{
MARIA EMÍLIA CUNHA ${ }^{1}$, HUGO QUENTAL ${ }^{1}$, ANA BARRADAS ${ }^{1}$, \\ PEDRO POUSÃO-FERREIRA ${ }^{1}$, ELSA CABRITA ${ }^{2}$ and SOFIA ENGROLA ${ }^{2}$ \\ ${ }^{1}$ INRB, I.P. / IPIMAR, Estação Piloto de Piscicultura de Olhão, Av. 5 de Outubro s/n, 8700-305 Olhão, Portugal. \\ E-mail: micunha@ipimar.pt \\ ${ }^{2}$ CCMar, Universidade do Algarve, Campus de Gambelas, 8005-139 Faro, Portugal.
}

\begin{abstract}
SUMMARY: One of the major obstacles to propagating dusky grouper, Epinephelus marginatus, is the difficulty of rearing the early larvae. We have successfully raised dusky grouper larvae in mesocosms using a mixed diet of endogenous plankton grown in the rearing tank and an exogenous supply of Brachionus plicatilis and Artemia sp. Newly hatched larvae at an initial density of 1.3 ind. $1^{-1}$ were stocked in partially shaded $3 \mathrm{~m}^{3}$ circular outdoor tanks during the summers of 2007 and 2008. Before introducing newly hatched larvae, the water was left for six days to promote plankton growth. Larval growth occurred at two different rates: i) a faster rate from first feeding to the beginning of metamorphosis, and ii) a slower rate at transformation. Survival at the beginning of metamorphosis was less than 10\% (33 DPH) in 2007 and between 25 and $50 \%$ (25 DPH) in 2008. High mortalities were observed during larval transformation. The estimated minimum food requirement per grouper larvae increased more than $300 \%$ from the beginning of the notochord flexion to the beginning of metamorphosis. To meet such a high feeding requirement the number of larger prey organisms/copepods in the mesocosm should be eight times higher during this time period.
\end{abstract}

Keywords: larval rearing, Epinephelus marginatus, dusky grouper, feeding requirement, mesocosm.

RESUMEN: La cría de larvas de mero, Epinephelus marginatus (Lowe, 1834), (Pisces: Serranidae), en un mesocosmos DE TECNOLOGíA SEMIEXTENSIVA. - Uno de los principales obstáculos para la propagación del mero, Epinephelus marginatus, ha sido la dificultad de la cría larvaria. Hemos conseguido la cría exitosa de larvas de mero en un mesocosmos utilizando una dieta mixta de plancton endógeno, desarrollado en el tanque de cría con suministro externo de Brachionus plicatilis y Artemia sp. Las larvas recién eclosionadas, con una densidad inicial de 1.3 ind.1.-1 se colocaron en tanques circulares de $3 \mathrm{~m}^{3}$, al aire libre y parcialmente a la sombra, durante los veranos de 2007 y 2008 . Antes de la introducción de las larvas recién eclosionadas, el agua se dejó durante seis días para promover el crecimiento del plancton. El crecimiento larvario se produjo a dos tasas distintas: i) más alta desde el inicio de la alimentación a la metamorfosis y ii) más baja durante la transformación. La supervivencia al inicio de la metamorfosis fue inferior al 10\% (33 DPH) en 2007 y entre el 25 y el 50\% (25 DPH) en 2008. Se observó una alta mortalidad de las larvas durante la transformación. La estimación del requerimiento alimenticio mínimo de las larvas de mero aumentó más del 300\% desde el comienzo de la flexión de la notocorda hasta el inicio de la metamorfosis. Para satisfacer tan altos requerimientos alimenticios el número de grandes presas/copépodos en el mesocosmos debería ser de ocho veces durante este período de tiempo.

Palabras clave: cría larvaria, Epinephelus marginatus, mero, requerimientos alimenticios, mesocosmos.

\section{INTRODUCTION}

The dusky grouper, Epinephelus marginatus (Lowe, 1834), is a highly prized marine fish im- portant for both commercial fisheries and game fishing. Globally they are distributed in the eastern and southwest Atlantic and western Indian Ocean, where they are associated with rocky bottoms in 
depths ranging from shallow to $50 \mathrm{~m}$ (Heemstra and Randall, 1993). Solitary and territorial, they can be found by spearfishers and scuba divers in rocky caves. They are sequential hermaphrodites, in which the hermaphroditism is protogynous (female-male) and monandric (males are the terminal sex, only produced through sexual transition). In the wild, females are considered to be mature between $2.5 \mathrm{~kg}(\sim 5 \mathrm{yr})$ and $11 \mathrm{~kg}(\sim 7 \mathrm{yr})$, and only large individuals (more than $9 \mathrm{~kg}$ ) occur as males. Sexual inversion occurs between 10 and 16 years of age (Pierre et al. 2008). With a minimum population doubling time of 4.5 to 14 years this species has low resilience and their vulnerability to exploitation is very high; therefore, they are listed as an endangered species (EN A2d) by the International Union for Conservation of Nature and Natural Resources (IUCN) (IUCN, 2008).

Due to its high market value and the need for seedling production for restocking programs and aquaculture, research into E. marginatus started in the mid 1990s (Spedicato et al., 1995; Glamuzina et al., 1998; Marino et al., 1998; La Mesa et al., 2008) with studies on breeding, artificial spawning and rearing of early stages. Since then considerable progress has been made on induced reproduction (Marino et al., 2001; 2003; Cabrita et al., 2009), but larval rearing is still difficult due to poor first feeding, which results in high mortality of larvae (Spedicato et al., 1995; Glamuzina et al., 1998).

Obtaining dusky grouper juveniles produced in aquaculture for stock enhancement is still a major challenge since newly hatched grouper larvae have mouth gapes that are too small for traditional live feeds and they have limited yolk reserves (Kohno et al., 1997; Doi et al., 1997; Glamuzina et al., 1998; Tucker, 1999; Spedicato and Boglione, 2000; Toledo et al., 2002). Consequently, successful larval rearing depends not only on the availability of a nutritionally adequate food supply (Watanabe and Kiron, 1994; Rainuzzo et al., 1997; Planas and Cunha, 1999) but also on the size of the prey, which need to be smaller than rotifers $(<100 \mu \mathrm{m})$ (Doi et al., 1997; Glamuzina et al., 1998).

In nature a wide range of organisms is available to the fish larvae. This includes not only all stages of copepods, but also much more abundant phytoplankton and protozoan organisms of smaller sizes. The natural bloom method used in semi-extensive mesocosms (van der Meeren and Naas, 1997; Divanach and Kentouri, 2000) is a methodology based on the bloom of a pelagic food chain of wild origin that de- velops a zooplanktonic segment of highly nutritious individuals (athecate protozoans such as Strobilidium sp. and Synchaeta sp. as well as copepod nauplii) (Kentouri and Divanach, 1986). These zooplankters are an appropriate size for dusky grouper larvae, which have a 220-250 $\mu \mathrm{m}$ mouth gape (Glamuzina et al., 1998; Russo et al., 2009) and a standard length between 2.4 and $2.6 \mathrm{~mm}$ at first exogenous feeding (our own data). The duration of the high performing zooplanktonic food chain is long enough for larvae to reach a size that is compatible with Brachionus feeding and later with Artemia.

In the 2007 egg production season we tried using the natural food chain method complemented with rotifers (Brachionus plicatilis) followed by Artemia sp. to raise dusky grouper larvae obtained from artificially fertilized eggs of wild adult groupers kept in captivity. The results were promising and in 2008 we proceeded with a similar technology with improvements based on the previous experience. This work describes the experiments in which dusky grouper larvae were raised successfully and presents results on their growth and survival.

\section{MATERIALS AND METHODS}

In this study we used the facilities of the Aquaculture Research Station (EPPO), of the National Institute of Biological Resources (INRB-IPIMAR), based in Olhão, southern Portugal. Fertilized dusky grouper eggs were obtained from a captive broodstock maintained for 5 years in one indoor tank $\left(10.6 \mathrm{~m}^{3}\right)$ at the EPPO facilities with a mean density of $4.0 \mathrm{~kg} \mathrm{~m}^{-3}$. A diet of fresh/frozen squid (Loligo gahi) and pilchard (Sardina pilchardus) were handfed ad libitum once a day. The water temperature ranged between $12^{\circ} \mathrm{C}$ in winter and $25^{\circ} \mathrm{C}$ in summer, and during spawning the temperature was $22.5^{\circ} \mathrm{C}$. Females were hormonally induced to spawn following the procedure described in Marino et al. (2003). Males were obtained from hormonally sex inverted juveniles according to Cabrita et al. (2009). Eggs were collected in sterile plastic containers by applying a gentle pressure on the abdomen in a caudalcranial direction, and fertilization was performed by the wet method (Marino et al. 2003).

Fertilized eggs were transferred to 2001 cylinder-conical fibreglass incubation tanks with a flow-through of filtered and UV sterilized sea water $\left(\mathrm{T}=21^{\circ} \mathrm{C}, \mathrm{pH}=8.0, \mathrm{~S}=37.5\right)$ and gentle aera- 
TABLE 1. - Experimental settings for dusky grouper egg incubation and larval rearing during 2007 and 2008.

\begin{tabular}{|c|c|c|}
\hline & Egg incubation & Larval rearing \\
\hline Rearing units & Indoor; 2001 cylinder-conical fibreglass & Outdoor; 30001 circular $(\varnothing 2.10 \mathrm{~m})$ fibreglass \\
\hline Water inlet & Bottom, near the tip of the conical edge & Bottom, near the wall \\
\hline Water outlet & $\begin{array}{l}\text { Top, outlet protected with } 500 \mu \mathrm{m} \text { nylon mesh } \\
\text { banjo type screen }\end{array}$ & $\begin{array}{l}\text { Top, outlet diametrically opposed to } \\
\text { inlet and protected with removable screen of } \\
\approx 500 \mathrm{~cm}^{2} \text { open area made of: } \\
\text { 1) } 80 \mu \mathrm{m} \text { nylon mesh, before Artemia co-feeding; } \\
\text { 2) } 150 \mu \mathrm{m} \text { nylon mesh during Artemia co-feeding } \\
\text { and wet feed } \\
\text { 3) } 500 \mu \mathrm{m} \text { and } 1000 \mu \mathrm{m} \text { nylon mesh during } \\
\text { dry feed regime }\end{array}$ \\
\hline Aeration system & $\begin{array}{l}\text { Bottom and around outlet filter to } \\
\text { prevent clogging. }\end{array}$ & $\begin{array}{l}\text { Air bubbling with no diffusers: one at centre, } 2 \text { laterals } \\
\text { diametrically opposed and one below outlet filter. } \\
\text { Wooden diffusers used during dry feed regime }\end{array}$ \\
\hline Water renewal & $\begin{array}{l}\text { One total renewal per hour before hatching } \\
\text { Two total renewals per hour after hatching }\end{array}$ & See Fig. 1 \\
\hline Photoperiod & $16 \mathrm{~h}$ light, $8 \mathrm{~h}$ dark & Natural, 14 hour light, $10 \mathrm{~h}$ dark \\
\hline
\end{tabular}

tion (see Table 1 for the detailed experimental settings). Before being freed into the mesocosm tank newly hatched larvae were left to acclimatize to the rearing temperature in 51 plastic containers floating in the tank.

The mesocosm experiments were performed outdoors in shaded (top covered 2.5 meters above the water to protect from direct sun rays) $3 \mathrm{~m}^{3}$ circular tanks during July and August 2007 and 2008. Only one tank was used each year for the larval rearing experiment. Seawater from the Ria Formosa coastal lagoon (Algarve, Portugal) was filtered through a
$500 \mu \mathrm{m}$ plankton mesh to seed the tanks with natural plankton and eliminate potential predators. After filling, the water was left stagnant for 6 days under natural light and temperature to allow the microzooplankton to develop before seeding the tanks with newly hatched fish larvae. This is a critical step that allows the development of natural plankton blooms that are the main food source in the initial days after the larvae open their mouths. The water circulation, aeration system and water renewal rate for larval rearing in both years is described in Table 1 and Figure 1. Water renewal was adjusted to guarantee

2007

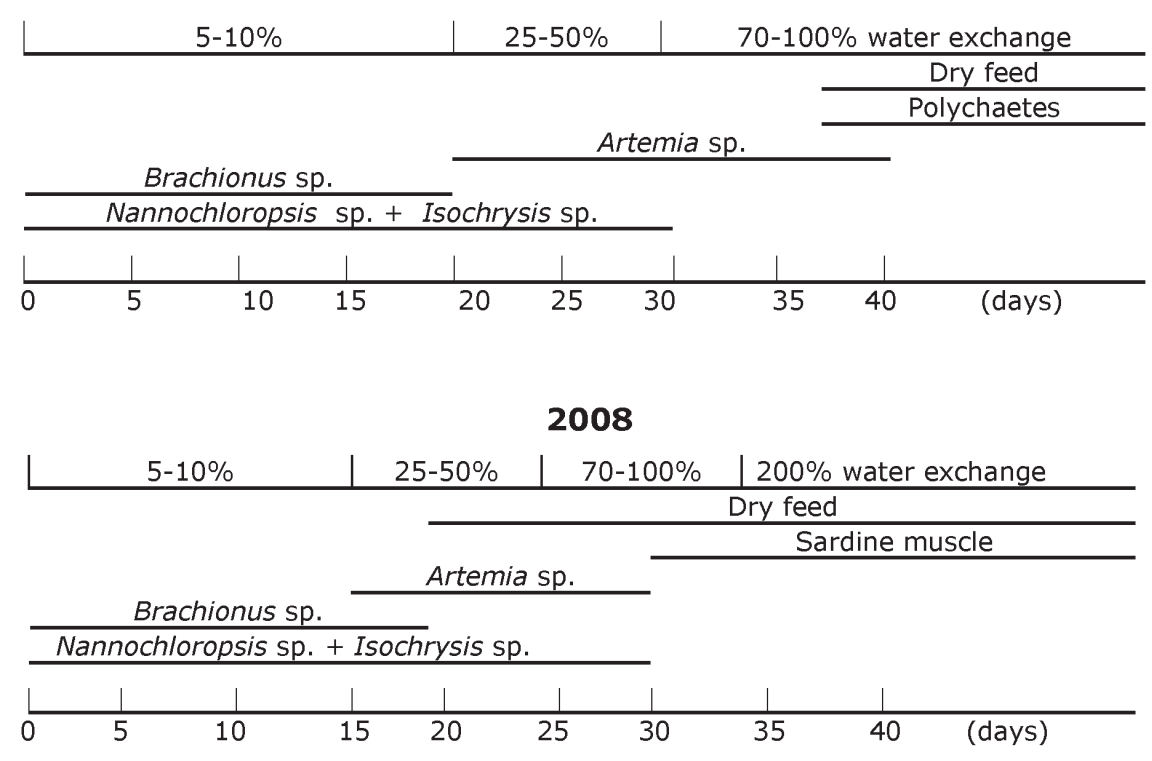

FIG. 1. - Water exchange and feeding schedule. 
minimum dissolved oxygen levels higher than 5 mg. $\mathrm{l}^{-1}$. A surface skimmer was used between $2 \mathrm{DPH}$ and $15 \mathrm{DPH}$ to prevent formation of oil films on the water surface.

Prey density has a large effect on feeding in marine fish larvae (Hunter, 1981). Since average densities in enclosed coastal areas can exceed $200 \mathrm{l}^{-1}$ (Hunter, 1981), we used this value as a minimum food concentration. Besides the endogenous prey developed in the tanks, food abundance was increased after larvae mouth opening by daily addition of enriched rotifers (Brachionus plicatilis) and later on by newly hatched and enriched Artemia sp.. The feeding schedule is shown in Figure 1. In 2007 the minimum food density was checked daily and if the plankton concentration was lower than 200 individuals. $1^{-1}$, small rotifers were supplied (for the first 3 weeks) followed by Artemia sp. nauplii (1.5 weeks) and increasing sizes of metanauplii until the end of the rearing period when dry feed was supplied, which lasted approximately five weeks. In 2008 the amount of supplied rotifers was 2.5 times higher then in 2007 during an identical period. Cofeeding of rotifers and Artemia nauplii was adopted in 2008 with an earlier start and a much shorter period of Artemia feeding than in 2007 (2 weeks). Dry feed was also introduced earlier during 2008.

Rotifers were enriched with Nannochloropsis oculata for $24 \mathrm{~h}$ and one day for Artemia with $\mathrm{RICH}^{\circledR}$ (Catvis, Hertogenbosh, Netherlands) following the manufacturer's instructions. Simultaneously with the first addition of rotifers, 101 of a mixture of Nannochloropsis oculata and Isochrysis galbana in equal parts were added to the tanks in a pseudo-green water methodology, and whenever the tank bottom was visible more algae were supplied. Addition of algae had three objectives: I) to feed the plankton, II) to create a more protected environment for early larvae (avoid direct sunlight), and III) to reduce cannibalism in older larvae by shading the water. Newly hatched Artemia were supplied to the rearing tanks after testing that they were accepted by the grouper larvae. In 2007 this was carried out at 20 days post hatch (DPH) while in 2008 it was carried out at $15 \mathrm{DPH}$. Five days later there was a shift to one day enriched Artemia and small amounts of commercial formulated feed (Lucky Star ${ }^{\circledR}$, Hung Kuo Industrial Co. Ltd, Taiwan). Feed rations were manually delivered hourly from 8:00 to 12:00 and before live prey distribution. After larval settlement larger types of natural food, polychaetes Nereis virens (SEABAIT $^{\circledR}$, Shoreline Polychaetes Farms LLP, Lynemouth, UK) in 2007 and frozen and chopped sardine muscle in 2008 were supplied until complete weaning onto artificial diets. The formulated feed in micropellets $(\approx 500 \mu \mathrm{m})$ was distributed manually 3 times a day: in the early morning, at midday and late afternoon.

The local air temperature and solar radiation were determined with a CR 200 Series meteorological station (Quantific ${ }^{\circledR}$, Coimbra, Portugal). The temperature, salinity, dissolved oxygen and $\mathrm{pH}$ of the water in the tanks was determined daily in the morning and afternoon using a multiparameter water quality portable meter (HI9828 Hanna Instruments Portugal $^{\circledR}$, Póvoa de Varzim, Portugal). The plankton concentration in the tanks was determined early in the morning prior to larval feeding in one litre water samples from the centre of the tank. The water was filtered through a $55 \mu \mathrm{m}$ size mesh and the plankton was preserved in $4 \%$ formaldehyde and analyzed in toto under a stereomicroscope.

We needed to have an indication of whether the grouper larvae were ingesting the food particles present in the tanks. Since we did not want to sacrifice or handle the larvae we used the attrition of food particles as an indication of feeding. The daily attrition of food particles in the tanks was the result of several undetermined factors, such as zooplankton natural mortality, ingestion by the larvae and washing out due to water exchange. Zooplankton intrinsic production in the tanks counteracts the decrease in food particles, but this is also an unknown factor.

Daily Attrition of Food Particles during day $n$ $\left(\operatorname{AtFP}_{n}\right)$ was calculated as the number of Total Available Food Particles during day $n\left(\right.$ TAFP $\left._{n}\right)$ minus the number of food particles present in the water before feeding (8:30) the next day (Counted Food Particles - $\left.\mathrm{CFP}_{n+1}\right)$. The formula was:

$$
\mathrm{AtFP}_{n}=\mathrm{TAFP}_{n}-\mathrm{CFP}_{n+1}
$$

with $\mathrm{TAFP}_{n}=\left(\mathrm{CFP}_{n}+\mathrm{DDFP}_{n}\right)$, the sum of Counted Food Particles in the water at 8:30 during day $n$ $\left(\mathrm{CFP}_{n}\right)$ and the Daily Delivered Food Particles during the same day $n\left(\mathrm{DDFP}_{n}\right)$. This last parameter is equal to the Delivered Food Particles at 9:00 $\left(\mathrm{DFP}_{n 9}\right)$ plus the Delivered Food Particles at 16:00 ( $\left.\operatorname{DFP}_{n 16}\right)$ during day $n$.

Growth in length was determined from the exponential regression of standard length on days after hatching: 


$$
L_{t}=L_{0} e^{G t}
$$

where $L_{t}$ is the length at time $t$ days, $G$ is the instantaneous daily growth (in length) coefficient and $L_{0}$ is standard length at hatching. Specific growth rate, in length, (percent per day) was determined as $100\left(e^{G}-1\right)$.

Larval measurements were taken under a binocular microscope using an incorporated micrometer with an accuracy of $0.1 \mathrm{~mm}$. Before and during notochord flexion, standard length (SL) was measured from the tip of the upper jaw to the end of the notochord. After notochord flexion, SL was measured from the tip of the upper to the posterior margin of the hypurals. All the individuals were photographed. In 2007 only a small numbers of individuals (13 in total) were measured from day 10 to 35 post hatch. In 2008, 140 larvae were measured from day 1 to 35 post hatch, and each daily mean was determined for 10 individuals. During this year, sampling was performed daily during the first $4 \mathrm{DPH}$, every second day until $16 \mathrm{DPH}$, and every 5 days until $35 \mathrm{DPH}$. All specimens were collected near the surface. The terminology used to refer to dusky groper early life history stages follows Kendal et al. (1984) and Colin et al. (1996).

The minimum energy requirements of larvae for growth were estimated by adapting the methodology followed by Yoshinaga et al. (1994) in which they assess metabolism and ingestion through respiration and dry weight. To calculate grouper larvae dry weight (DW) we first converted the larval length into ungutted wet weight using a power regression obtained with older larvae and juveniles (33 mm to $123 \mathrm{~mm}$ ) and assumed the DW to be equal to $20 \%$ the WW. Respiration was estimated based on the following regression equation between respiration rate, $\mathrm{R}$ (in $\mu \mathrm{O}_{2}$ ind. $\mathrm{h}^{-1}$ ), and body dry weight, DW (in mg.ind ${ }^{-1}$ ) for red sea bream (Pagrus major) post larvae and juveniles at $20^{\circ} \mathrm{C}$ (Yoshinaga et al., 1994):

$$
R=3.75 D W^{0.92}
$$

These respiration rates can be considered as the routine metabolism $\left(\mathrm{R}_{\text {rout }}\right)$ since they did not include either active swimming or feeding energy loss as described by Yoshinaga et al. (1994). To account for daily energy losses of larvae, $R_{\text {rout }}$ was multiplied by 2.0 to obtain the active feeding metabolic rate. This conversion factor was only applied for the daytime (14.5 light $\mathrm{h}$ during the rearing period). The result- ing equation for calculating food ingestion was:

$$
F=2.0 \cdot 1.6 \mathrm{R}_{\text {rout }}=3.2 \mathrm{R}_{\text {rout }}
$$

The grouper is a carnivorous fish and therefore the respiration quotient should be close to 0.8 (Morioka, (1985) as given by Yoshinaga et al., (1994)). When the respiration quotient is $0.8,1 \mu \mathrm{l}$ of oxygen combusts $0.43 \mu \mathrm{g}$ of organic carbon. Similarly to $\mathrm{Pa}$ grus major (Yoshinaga et al., 1994), we assumed a carbon weight:dry weight conversion factor of 0.4 .

Based on the estimated respiration rates and body weights and taking into account the assumptions described above, minimum daily food requirements (in terms of carbon) were calculated for grouper larvae at the time of: mouth opening, oil globule exhaustion, the beginning of notochord flexion and the beginning of metamorphosis.

The individual dry weight of the main zooplankters (groups or species) present in the mesocosms was estimated according to the weight/length relationships in van der Meeren (1991) and in Uye (1982). The mean length of the pertinent taxa was taken from the literature. The dry weight was converted into carbon content assuming a conversion of $43 \%$ and $53 \%$ in the case of copepods and bivalvia and polychaeta respectively (Uye, 1982). The carbon content for rotifers and Artemia nauplii was based on Lubzens and Zmora (2003) and on Dhont and Van Stappen (2003) respectively.

All biotic and abiotic data were analyzed for normality and transformed when necessary. Means were tested for significance after checking for equality of variances, and the rejection level for the null hypothesis was $p<0.05$. All the biotic variables were Naperian log transformed with the exception of rotifers and Artemia, which were square root transformed.

\section{RESULTS}

Dusky grouper larvae were reared in outdoor mesocosms in southern Portugal during summer with mean values of solar radiation and air temperature during the rearing periods of 2007 and 2008 of $538 \pm 36.9(\mathrm{SD}) \mathrm{Wm}^{-2}$ and $513 \pm 40.2 \mathrm{Wm}^{-2}$ and $24.1 \pm 2.06^{\circ} \mathrm{C}$ and $24.2 \pm 1.17^{\circ} \mathrm{C}$ respectively. Since during rearing the variation in temperature between day and night was relatively small $\left(3.3 \pm 1.72^{\circ} \mathrm{C}\right.$ in 2007 and $3.2 \pm 1.44^{\circ} \mathrm{C}$ in 2008 ), water temperatures in the tanks were only slightly lower than the air 
TABLE 2. - Live feeding characteristics in 2007 and 2008 during the entire rearing (Whole period) and mixed feeding periods with rotifers (Rotifer period) and Artemia (Artemia period): time duration of each period (days), mean daily number of prey per litre, gross food composition (percentage) and mean daily attrition of prey.

\begin{tabular}{|c|c|c|}
\hline Dates: & 07 Jul - 14 Aug 2007 & $02-31 \mathrm{Jul} 2008$ \\
\hline Whole period & 38 & 32 \\
\hline Total prey & $890 \pm 422$ & $1850 \pm 1628$ \\
\hline Endogenous prey & $240(18 \%)$ & $242(12 \%)$ \\
\hline Rotifers & $782(59 \%)$ & $1591(81 \%)$ \\
\hline Artemia & $294(22 \%)$ & $138(7 \%)$ \\
\hline Prey attrition & $556 \pm 385$ & $1359 \pm 1,274$ \\
\hline Rotifer period & 20 & 17 \\
\hline Total prey & $1238 \pm 400$ & $2928 \pm 1,287$ \\
\hline Endogenous prey & $251(20 \%)$ & $308(11 \%)$ \\
\hline Rotifers & $963(80 \%)$ & $2614(89 \%)$ \\
\hline Artemia & $0(0 \%)$ & $6(0 \%)$ \\
\hline Prey attrition & $835 \pm 385$ & $2185 \pm 1,012$ \\
\hline Artemia period & 18 & 15 \\
\hline Total prey & $558 \pm 183$ & $326 \pm 81$ \\
\hline Endogenous prey & $226(39 \%)$ & $149(46 \%)$ \\
\hline Rotifers & $61(11 \%)$ & $10(3 \%)$ \\
\hline Artemia & $281(50 \%)$ & $166(51 \%)$ \\
\hline Prey attrition & $242 \pm 162$ & $158 \pm 89$ \\
\hline
\end{tabular}

temperatures, with values of $23.6 \pm 1.07^{\circ} \mathrm{C}$ and $23.5 \pm 0.86^{\circ} \mathrm{C}$ in 2007 and 2008 respectively, and were not significantly different $(t=-0.446, d f=59$, $p=0.657)$. Water salinity was $36.7 \pm 0.11$ in 2007 and $37.1 \pm 0.30$ in 2008 , slightly but significantly different $(t=6.237, d f=32, p<0.001)$. Mean dissolved oxygen decreased with rearing time and was significantly lower $(t=7.473, d f=55, p<0.001)$ when the larvae were fed with Artemia $\left(5.50 \pm 0.88 \mathrm{mg} . \mathrm{l}^{-1}\right)$ than when they were fed with rotifers $\left(6.99 \pm 0.69 \mathrm{mg} . \mathrm{l}^{-1}\right)$.

The abundance of live feed available to the larvae during the two rearing experiments (Table 2) shows that mean daily total prey in 2007 was half that in 2008. Feeding particles were composed mainly of a mix of endogenous plankton and rotifers (the rotifer period) for slightly more than half of the rearing period and by endogenous prey and Artemia (the Artemia period) in the second half (Fig. 1 and Table 2). In 2008 the amount of rotifers supplied to the larvae was much higher than in 2007, while the amount of Artemia was lower. Endogenous prey was not significantly different $(t=-0.615, d f=56, p=$ 0.541 ) between the two years when the whole period is considered, but in 2008 it was significantly higher ( $t=4.704, \mathrm{df}=27, P<0.001)$ during the first half of rearing (the rotifer period) in comparison with the second half (the Artemia period).

Natural zooplankton grown in the tanks made up part of the live food available to dusky grouper larvae during rearing. These endogenous preys were mainly composed of different developmental stages
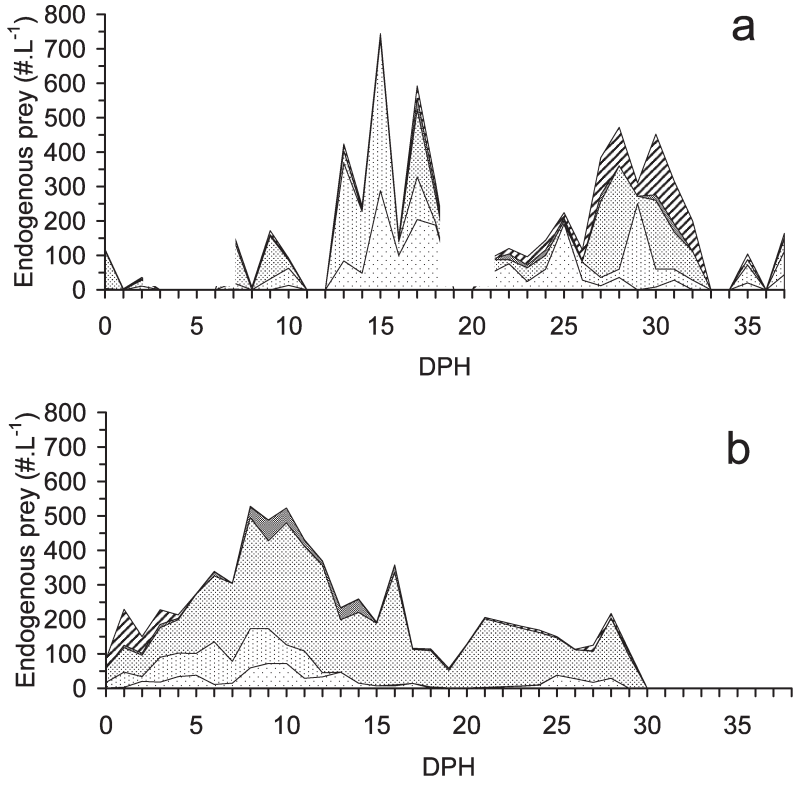

$\square$ Copepods : Copepodids $⿴$ Nauplii $\square$ Copepod eggs $\llbracket$ Other groups

FIG. 2. - Taxa and abundance succession of endogenous prey during the rearing period of 2007 (upper graph) and 2008 (lower graph).

of copepods belonging to several species of Acartia (A. clausi, A. grani, and A. margalefi) and Harpacticoids (Tisbe tenera, T. furcata and Euterpina acutifrons) and by other groups including bivalve trocophors, nectoquets of polychaetes, tintinnids and natural rotifers. The succession of zooplankton populations during the two rearing periods is shown in Figure 2. The first peak of zooplankton abundance in 2007 took place two weeks after the beginning of rearing while in 2008 it occurred one week after. In 2007 (Fig. 2 upper graph) the initial zooplankton population was mainly composed of copepod nauplii that developed into copepodites and adult copepods. These laid eggs that produced a large number of nauplii that, in addition to bivalve trocophors and nectoquets of polychaetes, constituted the second peak, which occurred 1 month after the incubation of the dusky grouper larvae. At the beginning of larval rearing in 2008 (Fig. 2 lower graph), blooms of Strobilidium sp. and Synchaeta sp. occurred followed by the development of a large number of copepod nauplii. The bloom of copepod nauplii occurred after the first week of rearing and lasted for almost one week. Table 3 summarizes the abundances of the different copepod stages and other groups available to the larvae during the rearing periods of 2007 and 2008, and provides information on their size range.

Daily attrition of food particles during the two rearing periods was highly correlated with food availability in the respective tanks $\left(\mathrm{R}^{2}=0.823 ; d f=37\right.$; 
TABLE 3. - Characteristics of endogenous live feed produced in the tanks during 2007 and 2008: mean abundance (number. $1^{-1}$ ) of prey items during the entire rearing period (Whole period) and during the mixed feeding periods with rotifers (Rotifer period) and Artemia (Artemia period). The size range of each group (adult copepods and copepodites - cephalothorax length; nauplii - trunk length; other groups - total length) is given in brackets.

Dates:

07 Jul-14 Aug 2007 02-31 Jul 2008

\begin{tabular}{lcc}
\hline Whole period & & \\
Adult copepods $(500>870 \mu \mathrm{m})$ & $54 \pm 70.7$ & $22 \pm 20.6$ \\
Copepodites $(390>830 \mu \mathrm{m})$ & $78 \pm 98.4$ & $51 \pm 41.8$ \\
Nauplii $(110>320 \mu \mathrm{m})$ & $76 \pm 80.2$ & $171 \pm 87.9$ \\
Other groups $(20>400 \mu \mathrm{m})$ & $38 \pm 47.6$ & $11 \pm 22.4$ \\
Rotifer period & & \\
Adult copepods $(500>870 \mu \mathrm{m})$ & $73 \pm 91.6$ & $28 \pm 22.8$ \\
Copepodites $(390>830 \mu \mathrm{m})$ & $109 \pm 127.5$ & $62 \pm 37.8$ \\
Nauplii $(110>320 \mu \mathrm{m})$ & $62 \pm 59.5$ & $200 \pm 98.3$ \\
Other groups $(20>400 \mu \mathrm{m})$ & $10 \pm 9.8$ & $12 \pm 29.1$ \\
Artemia period & & \\
Adult copepods $(500>870 \mu \mathrm{m})$ & $38 \pm 44.4$ & $13 \pm 12.8$ \\
Copepodites $(390>830 \mu \mathrm{m})$ & $42 \pm 14.4$ & $2 \pm 1.3$ \\
Nauplii $(110>320 \mu \mathrm{m})$ & $88 \pm 94.2$ & $128 \pm 46.6$ \\
Other groups $(20>400 \mu \mathrm{m})$ & $60 \pm 54.2$ & $6 \pm 4.8$ \\
& & \\
\hline
\end{tabular}

$p<0.001$ in 2007 and $\mathrm{R}^{2}=0.937 ; d f=28 ; p<0.001$ in 2008), with a mean value for prey attrition in 2007 that was lower but not significantly different $(t=-1.455, d f=52, p=0.076)$ from 2008 (Table $2)$. The amount of attrition during the rotifer period was 2.6 times lower in 2007 than in 2008. When the attrition of food particles per day was normalized to the amount of total available food (the attrition rate in Fig. 3), it is evident that attrition is low during the first days of rearing and progressively increases until day 10 post hatch, as can be seen in Figure 3 (lower graph). However, after this initial stage and during a subsequent period of seven days most of the food (90 to 95\%) in the tank had disappeared. This period of high attrition corresponded to rotifer feeding ( $\mathrm{R}$ in Fig. 3) after which there was a sharp decrease that seemed to coincide with the change of food from rotifers to Artemia, which also involved higher water renewal. A few days later the attrition rate increased but never to the levels seen during the rotifer period.

The growth in length of the individuals during the two rearing periods is shown in Figure 4. During 2008 there were two different trend lines in the growth curve: a) from first feeding to the beginning of metamorphosis, and b) transformation. The number of samples collected in 2007 was not enough to construct a similar curve because we did not sample enough individuals during transformation. Growth from first feeding to the beginning of metamorphosis was significantly higher in 2008 (ANCOVA, df $=113, p<0.001)$.
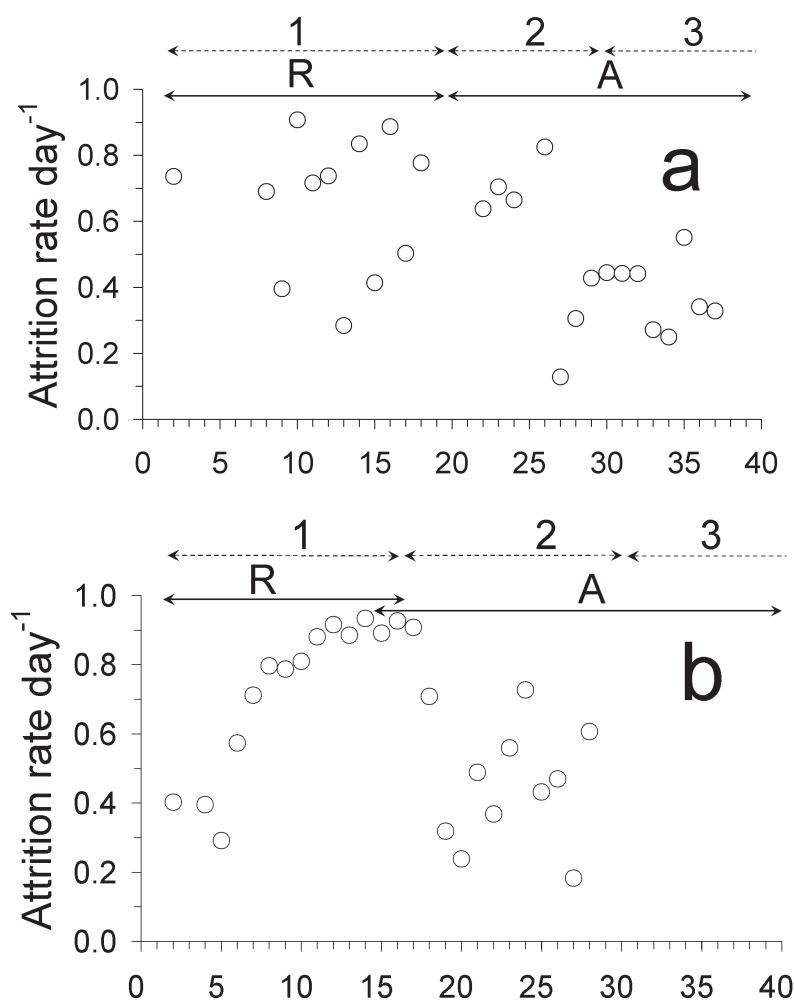

FIG. 3. - Attrition rates during 2007 (a) and 2008 (b). Numbers above each graph correspond to water exchange rates: $1-5$ to $10 \% ; 2-25$ to $50 \% ; 3-70$ to $100 \%$; and letters to the feeding scheduled: $\mathrm{R}$ - rotifer; A - Artemia.

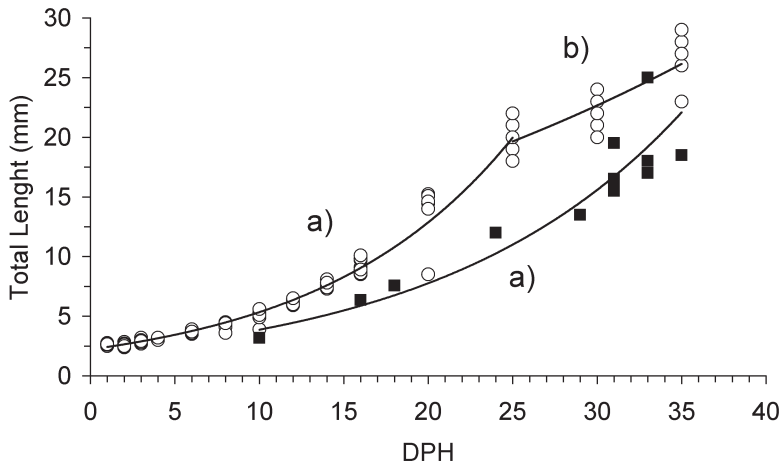

FIG. 4. - Growth in length of dusky grouper larvae during 2007 (black squares) and 2008 (white circles). Exponential lines: a, before metamorphosis; $b$, during transformation.

TABLE 4. - Characteristics of larval rearing during 2007 and 2008.

Dates:

09 Jul-14 Aug $2007 \quad$ 02-31 Jul 2008

\begin{tabular}{lcc}
\hline $\begin{array}{l}\text { Initial larval density } \\
\text { (number } 1^{-1} \text { ) }\end{array}$ & 1.3 & 1.5 \\
$\begin{array}{l}\text { Larval period } \\
\text { (days until metamorphosis) }\end{array}$ & 33 & 25 \\
$\begin{array}{l}\text { Time to settlement } \\
\text { (days) }\end{array}$ & 37 & 29 \\
$\begin{array}{l}\text { Survival at beginning } \\
\text { of metamorphosis (\%) }\end{array}$ & $<10$ & $\begin{array}{c}25-50 \\
6\end{array}$ \\
Survival at 60 DPH (\%) & 1 & \\
\hline
\end{tabular}


TABLE 5. - Regression coefficients describing growth in length of dusky grouper larvae before metamorphosis in 2007 and 2008 and during transformation in 2008. Percent gain - specific growth rate.

\begin{tabular}{rlcc}
\hline \multicolumn{1}{r}{ Year: } & 2007 & 2008 & 2008 \\
\hline Ontogenic stage: & Larva & Larva & Transformation \\
Stage duration $($ days): & 33 & 25 & 10 \\
Percent gain $\left(\% \mathrm{~d}^{-1}\right):$ & 7.5 & 9.2 & 2.9 \\
$N$ & 12 & 114 & 31 \\
Intersection $\left[\ln \left(L_{0}\right)\right]$ & $0.612 * *$ & $0.795 * * *$ & $0.0880 * * *$ \\
Slope $(G)$ & $0.0719 * * *$ & 0.0129 & $0.0286 * * *$ \\
$S E_{\left[\ln \left(L_{0}\right)\right]}$ & 0.1516 & 0.0011 & 0.0919 \\
$S E_{G}$ & 0.0055 & 0.985 & 0.0031 \\
$\mathrm{R}^{2}$ & 0.945 & & 0.752 \\
\hline
\end{tabular}

Signif. codes: $p<0.001 * * * ; p<0.01 * * ; p<0.05 *$

Table 6. - Carbon budget for metabolism and ingestion of dusky grouper larvae based on estimated respiration rate at $20^{\circ} \mathrm{C}$.

\begin{tabular}{|c|c|c|c|c|c|c|}
\hline \multirow{2}{*}{$\begin{array}{l}\text { Age } \\
\text { (DPH) }\end{array}$} & \multirow{2}{*}{$\begin{array}{l}\text { Standard length } \\
(\mathrm{mm})\end{array}$} & \multirow{2}{*}{$\begin{array}{l}\text { Body weight } \\
\left(\mu \mathrm{g} \mathrm{C} \text { ind }^{-1}\right)\end{array}$} & \multicolumn{2}{|c|}{ Routine metabolism } & \multicolumn{2}{|c|}{ Ingestion } \\
\hline & & & $\left(\mu \mathrm{g} \mathrm{C}\right.$ ind. day $\left.{ }^{-1}\right)$ & $\left(\%\right.$ body $\mathrm{C}$ day $\left.^{-1}\right)$ & ( $\mu \mathrm{g} \mathrm{C}$ ind. day ${ }^{-1}$ ) & $\left(\%\right.$ body $\mathrm{C}$ day $\left.^{-1}\right)$ \\
\hline 2 & 2.7 & 14.8 & 1.9 & 12.6 & 6.0 & 40.3 \\
\hline 5 & 3.5 & 31.9 & 3.8 & 11.8 & 12.1 & 37.9 \\
\hline 15 & 7.9 & 411.9 & 39.8 & 9.7 & 127.2 & 30.9 \\
\hline 25 & 17.7 & 5311.7 & 417.9 & 7.9 & 1337.2 & 25.2 \\
\hline
\end{tabular}

The rearing characteristics of the dusky grouper larvae during the two years (Table 4) were very different, although the initial densities of newly hatched larvae were similar ( $1.3 \mathrm{l}^{-1}$ in 2007 and $1.5 \mathrm{l}^{-1}$ in 2008). During 2008 the larvae took less time to start metamorphosis, which occurred when larvae were 25 days old and $20 \pm 1.2 \mathrm{~mm}$ (SD) in total length, than in 2007, when the larvae took 33 days to reach a similar length (Fig. 4). Settlement, which started to occur at $22 \pm 1.3 \mathrm{~mm}$, was also earlier in 2008 (30 DPH) than in 2007 (37 DPH). This is reflected in the percentage of daily growth that in 2007 was $7 \%$ during the first larval stages (before metamorphosis) and in 2008 was 9\% (Table 5). During transformation the growth rate declined significantly (Fig. 4), and was 3\% per day in 2008 (Table 5). Survival at the beginning of transformation was estimated to be $<10 \%$ in 2007 and $25-50 \%$ in 2008 (Table 4). Sixty days post hatch, when all benthic juveniles were already well weaned onto dry food, survival was $1 \%$ in 2007 and $6 \%$ in 2008. High mortality during transformation was observed during both years.
The relationship between juvenile grouper body wet weight and standard length (SL) was highly significant and the power coefficient for SL was $3.156 \pm 0.020 \mathrm{SE}(t=154.648, d f=276, p<0.001)$ and the intercept $(\log a)$ was $-2.114 \pm 0.039 \mathrm{SE}(t=$ $-54.675, d f=276, p<0.001)$. This relation was used to determine individual dry weight of the smaller larvae that was then converted into carbon weight assuming a conversion factor of $40 \%$. Individual dry weight was also used to calculate the respiration rate as described in the Methods section using equation (3).

Information on mean larval length, body weight, metabolism and minimum daily food requirements (in terms of carbon) for larvae at the time of mouth opening (2 DPH), oil globule exhaustion (5 DPH), the beginning of notochord flexion (15 DPH) and the beginning of metamorphosis (25 DPH) is shown in Table 6. Body carbon weight at each larval stage was, respectively, 15, 32, 412 and 5,311 $\mu \mathrm{g} C$ lar$\mathrm{vae}^{-1}$. With increasing body size both metabolism and ingestion per unit body weight declined, from

TABLE 7. - Characteristics of prey size and the estimated minimum number of daily prey required by the different stages of dusky grouper larvae until the beginning of metamorphosis.

\begin{tabular}{|c|c|c|c|c|c|}
\hline \multirow[b]{2}{*}{$\begin{array}{l}\text { Age } \\
\text { (DPH) }\end{array}$} & \multirow[b]{2}{*}{$\begin{array}{l}\text { Standard length } \\
(\mathrm{mm})\end{array}$} & \multirow[b]{2}{*}{$\begin{array}{l}\text { Minimum food required } \\
\quad\left(\mu \mathrm{g} \mathrm{C} \text { ind. } \text { day }^{-1}\right)\end{array}$} & \multicolumn{2}{|c|}{ Size of prey } & \multirow[b]{2}{*}{$\begin{array}{l}\text { Minimum prey required } \\
\left(\text { ind. } \text { day }^{-1}\right)\end{array}$} \\
\hline & & & $\begin{array}{l}\text { Length range } \\
(\mu \mathrm{m})\end{array}$ & $\begin{array}{l}\text { Mean weight } \\
\left(\mu g \mathrm{C} \text { ind. } .^{-1}\right)\end{array}$ & \\
\hline 2 & 2.7 & 6.0 & $100-160$ & 0.06 & 94 \\
\hline 5 & 3.5 & 12.1 & $100-275$ & 0.24 & 51 \\
\hline 15 & 7.9 & 127.2 & $275-860$ & 1.9 & 67 \\
\hline 25 & 17.7 & 1337.2 & $610-860$ & 2.6 & 513 \\
\hline
\end{tabular}


12.6 to 7.9 and from 40.3 to $25.2 \%$ respectively, although the minimum daily carbon requirement increased with age. Assuming that at larvae mouth opening, i.e., at day 2 post hatch, grouper larvae eat only individuals between 100 and $160 \mu \mathrm{m}$, each larva will need to eat 96 individuals within this size range to fulfil its minimum daily carbon requirement (Table 7). As the larvae grow they eat larger prey and the minimum number of prey required per day decreases. However, at the beginning of metamorphosis $(\approx 25 \mathrm{DPH})$ the daily food requirement is high and, even considering only the larger zooplankters in the mesocosms and Artemia, the minimum number of prey per larvae is very high at 513 individuals.

\section{DISCUSSION}

Dusky grouper larvae are characterized by a small mouth gape and body size and poor reserves of endogenous nutrition (Glamuzina et al. 1998; Spedicato and Boglione, 2000; Gracia López and Castelló-Orvay, 2003). The results of this study show that larvae of dusky grouper can be successfully reared in mesocosms, using the natural bloom method with addition of rotifers and Artemia in later development stages. In the mesocosm, a large variety of prey of different sizes from phytoplankton to different larval stages of copepods was available to the grouper larvae to meet their basic nutritional needs. The daily attrition of food particles in the tanks could be related to the natural mortality of zooplankton, washing out due to water exchange and ingestion by the larvae. However, at the onset of rearing, a time when production of endogenous prey in the mesocosm is elevated and the water exchange is very low, attrition rates of 40 to $60 \%$ (Fig. 3) suggest that ingestion might be the determining factor. If so, dusky grouper might capture prey after the second day post hatch (DPH). Day 2 to 5 post hatch corresponded to the period of mixed feeding, when the larvae have not yet exhausted their own energetic reserves but have already started feeding on exogenous prey. This was the phase of the beginning of the zooplankton bloom. In 2008, after the initial period with high numbers of athecate protozoans (Tintinnids, Strobilidium sp. and Synchaeta sp.) (Fig 2 (lower graph)), copepod eggs, especially from the genus Acartia, started to hatch to produce a large number of nauplii. Daily sampling coverage during the rearing period of 2008 revealed that the attrition rate increased progressively after 5
DPH and at 10 DPH reached a maximum of $95 \%$ and remained high during the time of rotifer feeding (Fig. 3 - lower graph). Specific growth rates in length of dusky grouper larvae (Table 5) were high $\left(9 \%\right.$ day $\left.^{-1}\right)$, and at $10 \mathrm{DPH}$ the larvae attained an average length of $5.2 \mathrm{~mm}$, a size at which Brachionus spp. could easily be ingested (we observed that 15 DPH larvae were already able to eat instar I Artemia nauplii).

We observed that late-larvae of dusky grouper are visual feeders and that when near the food particle the feeding mode is "sucking/grasping". The same feeding mode is reported by Kohno et al. (1997) for Epinephelus coioides, and Yoseda et al. (2008) suggests that leopard coral groupers (Plectropomus leopardus) are also visual feeders with food intake increasing with light intensity. Although they are visual feeders, food preferences of dusky grouper larvae appear to be determined mostly by the encounter rate; the higher the abundance of endogenous prey and rotifers the higher the attrition of prey (Table 2). During the Artemia feeding period, when lower numbers of food organisms were supplied to the larvae, the attrition rate decreased drastically (Fig. 3) even considering higher prey losses due to higher water exchange. This prey reduction may be the cause of the high larval mortality that we perceived starting at metamorphosis and during transformation. We observed at this time that a large number of the larvae became lethargic and cannibalism occurred. Pierre et al. (2008) in their review about grouper aquaculture reported that cannibalism during the metamorphosis stage is one of the problems affecting commercial larval rearing in Taiwan, where they feed with high protein pellets as prevention. In Gadus morhua large mortalities also occur around and after metamorphosis (Øiestad, 1985). As an explanation for this Folkvord (1991) suggested that cannibalism in combination with prey depletion during the period after metamorphosis could explain most of the mortalities.

Growth rates of Epinephelus marginatus to metamorphosis in our experiments were much higher then those observed for other species of Epinephelus, like E. coioides (Toledo et al. 1999), E. bruneus (Sawada et al., 1999) and E. suilus (Duray et al., 1997), among others. However, within the same species there is variability, as indicated by the larval growth and survival of E. marginatus during our 2007 and 2008 rearing periods. Although environmental conditions and initial densities of newly hatched larvae 


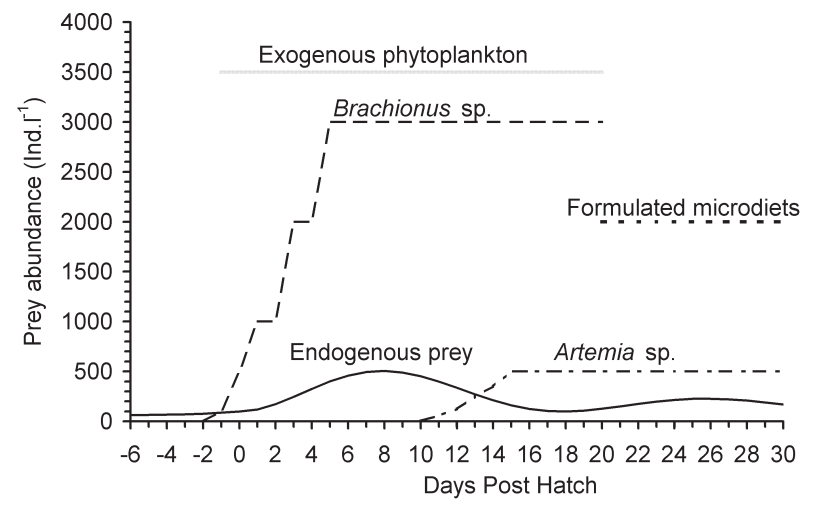

FIG. 5. - Idealized feeding scheme for rearing dusky grouper larvae in a semi-extensive mesocosm. (Exogenous phytoplankton and formulated microdiets are not to scale).

in the tanks were similar (Table 4), survival and growth (Table 5) were very different. This seems to be related to the much higher amount of food available to the larvae during 2008 in comparison to 2007 (Table 2), since prey density has been reported to have a large effect on feeding in marine fish larvae (Hunter, 1981). In 2008 not only was the bloom of endogenous plankton earlier then in 2007 (Fig. 2) but also numbers of available nauplii were higher (Table 3). As reported by van der Meeren and Mæss (1993), fish larvae need copepod nauplii to start growing and they actively select these nauplii for their energetic needs. Copepods have high nutritional value, particularly $n-3$ highly unsaturated fatty acids (n-3 HUFA), indispensable amino acids and vitamins that are essential for growth and survival of marine fish larvae (Sargent and Falk-Peterson, 1988; McEvoy et al. 1998; Støttrup, 2003; van der Meeren et al. 2008). Late (in the rearing period) production of nauplii in 2007 (Fig. 2) and in lower abundances (Table 3) may have retarded larval growth and possibly affected larval viability. To add to this lower nauplii production in 2007, the amount of rotifers supplied to the larvae during the rotifer period (Table 2) was also lower in comparison to the amount supplied in 2008. Consequently survival was higher at the onset of metamorphosis during 2008. However, during transformation mortality became high (Table 4), probably due to the reduced amount of available food during the Artemia period in 2008. Not only was the number of endogenous prey low but also the quantity of Artemia supplied was lower than in 2007.

Our results demonstrate that early larvae of the dusky grouper can be successfully reared at temperatures close to $23^{\circ} \mathrm{C}$ in semi-intensive systems (van der Meeren and Naas, 1997; Divanach and Kentouri,
2000). The tanks for rearing the larvae should be prepared in advance and filled with coarsely filtered $(500 \mu \mathrm{m})$ sea water 6 days before seeding with newly hatched larvae. This permits the development of microzooplankton whose maximum abundance coincides with the initial days after larvae mouth opening. In parallel with larval seeding, exogenous phytoplankton should be added to the tanks at a density of $3 \mathrm{ml}^{-\mathrm{l}^{-1}}$ of water to create shading, and food should be supplemented with increasing amounts of rotifers up to a density of 3000 rotifers $1^{-1}$ at $5 \mathrm{DPH}$ during the first 2 weeks. Although first feeding larvae may not feed directly on rotifers, small rotifer eggs are available. In Figure 5 we suggest a feeding plan based on our experimental results. Considering a density of 1 larva per litre the density of endogenous prey at seeding should be at least 100 ind $\mathrm{l}^{-1}$ (Table 7), of which $25 \%$ should be small ciliates and $60 \%$ small copepod nauplii. These numbers appear to be appropriate to propagate nauplii for first feeding larvae up to a size compatible with rotifer feeding at the exhaustion of the oil globule. If the concentration of endogenous zooplankton does not reach the above densities, additional filtered zooplankton $(55 \mu \mathrm{m})$ may be added to fulfil this requirement. At an age of 10 DPH, small amounts of recently hatched Artemia (5 ind. $1^{-1}$ ) should start to be supplied to the tanks in order to check their acceptability by the larvae. If Artemia are well accepted, the density should be increased steadily so that the total density of prey larger than $275 \mu \mathrm{m}$ should be at least 70 ind. $1^{-1}$ per larvae at $15 \mathrm{DPH}$. The minimum food requirement from this time until the beginning of metamorphosis $(\approx 25 \mathrm{DPH})$ increases exponentially and the number of larger prey organisms in the mesocosm at this age should be adjusted daily to attain a value higher than 520 per larvae at 25 DPH. Rotifer feeding should not be discontinued until 20 DPH in order to keep the level of encounter rates high. Specific growth rates of dusky grouper are high, and at this age they are well into the post-flexion stage with a mean total length of $11.8 \mathrm{~mm}$, which is a size compatible with larger prey like $24 \mathrm{~h}$ enriched Artemia. At the same time, shredded polychaetes and/or fish muscle pellets and high protein formulated feed in micropellets should be supplied to the larvae in controlled quantities in order to meet the high energy requirements of larvae at these ages and to decrease mortality and cannibalism during larval metamorphosis. 


\section{ACKNOWLEDGEMENTS}

We thank two anonymous reviewers for constructive comments on the submitted manuscript. This study benefited from funding by the Project PROMAR/SP5.P117/03 (programme INTERREG IIIA, co-funded by FEDER, European Commission).

\section{REFERENCES}

Cabrita, E., S. Engrola, L.E.C. Conceição, P. Pousão-Ferreira and M.T. Dinis. - 2009. Successful cryopreservation of sperm from sex-reversed dusky grouper, Epinephelus marginatus. Aquaculture, 287: 152-157.

Colin, P.L., C.C. Koenig and W.A. Laroche. - 1998. Development from egg to juvenile of the red grouper (Epinephelus morio) (Pisces: Serranidae) in the laboratory. In: F. Arreguín-Sánches, J.L. Munro, M.C. Balgos, and D. Pauly (eds.), Biology, fisheries and culture of tropical groupers and snappers. ICLARM Conf. Proc., 48: 399-414.

Dhont, J. and G. van Stappen. - 2003. Biology, tank production and nutritional value of Artemia. In: J. Støttrup and L.A. McEvoy (eds.), Live feed in marine aquaculture, pp. 65-112. Blackwell Publishing, Oxford.

Divanach, P. and M. Kentouri. - 2000. Hatchery techniques for specific diversification in Mediterranean finfish larviculture. In: B. Basurco, (ed.), Mediterranean marine aquaculture finfish species diversification. Cah. Options Méditerr., 47: 75- 87.

Doi M., J.D. Toledo, M.S.N. Golez, M. de los Santos and A. Ohno. - 1997. Preliminary investigation of feeding performance of larvae of early red-spotted grouper, Epinephelus coioides, reared with mixed zooplankton. Hydrobiologia, 358: 259-263.

Duray, M., C. B. Estudillo and L.G. Alpasan. - 1997. Larval rearing of the grouper Epinephelus suillus under laboratory conditions. Aquaculture, 150: 63-76.

Folkvord, A. - 1991. Growth, survival and cannibalism of cod juveniles (Gadus morhua L.): effects of feed type, starvation and fish size. Aquaculture, 97: 41-59.

Glamuzina, B., B. Skaramuca, N. Glavic, V. Kozul, J. Dulcic and M. Kraljevic. - 1998. Egg and early larval development of laboratory reared dusky grouper Epinephelus marginatus (Lowe, 1834) (Pisces, Serranidae). Sci. Mar., 62(4): 373-378.

Gracia López, V. and F. Castelló-Orvay. - 2003. Preliminary data on the culture of juvenile of the dusky grouper, Epinephelus marginatus (Lowe, 1834). Hidrobiológica, 13: 321-327.

Heemstra, P.C. and J.E. Randall - 1993. Groupers of the world (Family Serranidae, Subfamily Epinephelinae). An annotated and illustrated catalogue of the grouper, rockcod, hind, coral grouper and lyretail species know to date. FAO Species Catalogue, FAO Fisheries Synopsis, 125, Rome.

Hunter, J.R. - 1981. Feeding ecology and predation of marine fish larvae. In: R. Lasker (ed.), Marine fish larvae: morphology, ecology and relation to fisheries, pp. 33-77, University of Washington Press.

IUCN 2008. 2008 IUCN Red List of Threatened Species. <www. iucnredlist.org $>$. Downloaded on 15 August 2008.

Kendall, A.W., Jr., E.H. Ahlstrom and H.G. Moser. - 1984. Early life history of fishes and their characters. In: H.G. Moser, W.J. Rochards, D.M. Cohen, M.P. Fahay, A.W. Kendall, Jr. and S.L. Richardson, (eds.), Ontogeny and systematic of Fishes. Am. Soc. Ichthyol. Herpetol., Spec. Publ., 1: 11-12.

Kentouri M., and P. Divanach. - 1986. Sur L'importance des ciliés pelagiques dans l'alimentation des stades larvaires de poisson. Année Biologique, 25: 307-316

Kohno H., R.S. Ordino-Aguilar, A. Ohno and Y. Taki. - 1997. Why is grouper larval rearing difficult?: an approach from the development of the feeding apparatus in early stage larvae of the grouper, Epinephelus coioides. Ichthyol. Res., 44: 267-274.

La Mesa, G, A. Longobardi, F. Sacco and G. Marino-- 2008. First release of hatchery juveniles of the dusky grouper Epinephelus marginatus (Lowe, 1834) (Serranidae: Teleostei) at artificial reefs in the Mediterranean: results from a pilot study. Sci. Mar., 72(4): 743-756.

Lubzens, E. and O. Zmora. - 2003. Production and nutritional value of rotifers. In: J. Støttrup and L.A. McEvoy (eds.), Live feed in marine aquaculture, pp. 17-52. Blackwell Publishing, Oxford.

Marino, G., E. Azzurro, C. Boglione, A. Massari and A. Mandich. 1998. Induced spawning and first larval rearing in Epinephelus marginatus. In: B. Melchior (ed.), Symposium International sur les mérous de méditerranée, pp. 139-142. Mémoires de l'Institut Océanographique Paul Ricard.

Marino, G., E. Azzurro, A. Massari, M.G. Finoia and A. Mandich. - 2001. Reproduction in the dusky grouper from the southern Mediterranean. J. Fish Biol., 58: 909-927.

Marino, G., E. Panini, A. Longobardi, A. Mandich, M.G. Finoia, Y. Zohar and C.C. Mylonas. - 2003. Induction of ovulation in captive-reared dusky grouper Epinephelus marginatus (Lowe, 1834), with a sustained-release GnRHa implant. Aquaculture, 219: 841-858

McEvoy, L., T. Næss, J.G. Bell, and O. Lie. - 1998. Lipid and fatty acid composition of normal and malpigmented Atlantic halibut (Hippoglossus hippoglossus) fed enriched Artemia: a comparison with fry fed wild copepods. Aquaculture, 163: 235-248.

Morioka, Y. - 1985. Growth, respiration and food requirement of flounder, Paralichthys olivaceus, in its early life history. Bull. Seikai Reg. Fish. Res. Lab., 62: 67-77.

Pierre, S., S. Gaillard, N. Prévot-D'Alvise, J. Aubert, O. RostaingCapaillon, D. Leung-Tack and J. P. Grillasca. - 2008. Grouper aquaculture: Asian success and Mediterranean trials. Aquatic. Conser: Mar. Freshw. Ecosyst., 18: 297-308.

Øiestad, V. - 1985. Predation on fish larvae as a regulatory force, illustrated in mesocosm studies with large groups of larvae. NAFO Sci. Counc. Studies, 8: 25-32.

Planas, M. and I. Cunha. - 1999. Larviculture of marine fish: problems and perspectives. Aquaculture, 177: 1-15.

Rainuzzo, J.R., K.I. Reitan and Y. Olsen. - 1997. The significance of lipids at early stages of marine fish: a review. Aquaculture, 155: 103-115.

Russo, T., C. Boglione, P. Marzi and S. Cataudella. - 2009. Feeding preferences of the dusky grouper (Epinephelus marginatus, Lowe 1834) larvae reared in semi-intensive conditions: A contribution addressing the domestication of this species. Aquaculture, 289: 289-296.

Sargent, J.R. and S. Falk-Peterson. - 1988. The lipid biochemistry of calanoid copepods. Hydrobiologia, 167/168, 101-114.

Spedicato, M.T. and C. Boglione. - 2000. Main constraints in the artificial propagation of the dusky grouper Epinephelus marginatus (Lowe, 1834): three years experimental trials on induced spawning and larval rearing. In: E. Chioccioli (ed.), Recent Advances in Mediterranean Aquaculture Finfish Species Diversification, 47: 227- 234.

Spedicato, M.T., G. Lembo, P. Di Marco and G. Marino. - 1995. Preliminary results in the breeding of dusky grouper Epinephelus marginatus (Lowe, 1834). Cah. Options Méditerr., 16: 131-148.

Sawada, Y., K. Kato, T. Okada, M. Kurata, Y. Mukai, S. Miyashita, O. Murata and H. Kumai. - 1999. Growth and morphological development of larval and juvenile Epinephelus bruneus (Perciformes: Serranidade). Ichthyol. Res., 46(3): 245-257.

Støttrup, J. - 2003. Production and nutritional value of copepods. In: J. Støttrup and L.A. McEvoy (eds.), Live feed in marine aquaculture, pp. 145-205. Blackwell Publishing, Oxford.

Toledo, J.D., D. Chavez and J. Rodriguez Jr. - 2004. Studies on Semiintensive seed production of grouper (Epinephelus coioides). In: M.A. Rimmer, S. McBride and K.C. Williams (eds.), Advances in grouper aquaculture. ACIAR Monograph 11: 55-60.

Tucker, J.W. - 1999. Species profile: Grouper aquaculture. South. Reg. Aquac. Centre: $1-721$

Uie, S. - 1982. Length-weight relationships of important zooplankton from the inland Sea of Japan. J. Oceanogr. Soc. Japan, 38: $149-158$.

van der Meeren, T. - 1991. Selective feeding and prediction of food consumption in turbot larvae (Scophthalmus maximus L.) reared on the rotifer Brachionus plicatilis and natural zooplankton. Aquaculture, 93: 35-55.

van der Meeren, T. and T. Næss. - 1993. How does cod (Gadus morhua L.) cope with variability of feeding conditions during early larval stages? Mar. Biol., 116: 637-647. 
van der Meeren, T. and K.E. Naas. - 1997. Development of rearing techniques using large enclosed ecosystems in the mass production of marine fish fry. Rev. Fish. Sci., 5: 367-390.

van der Meeren, T., R. E. Olsen, K. Hamre and H. J. Fyhn. - 2008. Biochemical composition of copepods for evaluation of feed quality in production of juvenile marine fish. Aquaculture, 274: 375-397.

Watanabe, T and V. Kiron. - 1994. Prospects in larval fish dietetics. Aquaculture, 124: 223-251.

Yoseda, K., K. Yamamoto, K. Asami, M. Chimura, K. Hashimoto and S. Kosaka. - 2008. Influence of light intensity on feeding, growth, and early survival of leopard coral grouper (Plectropomus leopardus) larvae under mass-scale rearing conditions. Aquaculture, 279: 55-62.

Yoshinaga, K., J. Hiromi and S. Kadota. - 1994. Respiration and food requirement by larvae and juveniles of red sea bream, Pagrus major. Bull. Coll. Agr. \& Vet. Med., Nihon Univ., 51: 174-181.

Received November 14, 2008. Accepted June 25, 2009. 